\title{
Implications of the Second World War us Refugee Resettlement Efforts of Cecilia Razovsky and Varian Fry
}

Stacey Shaw

Brigham Young University - Provo, stacey_shaw@byu.edu

Follow this and additional works at: https://scholarsarchive.byu.edu/facpub

Part of the Migration Studies Commons

\section{Original Publication Citation}

Shaw, S.A. (2018). Implications of the World War II U.S. refugee resettlement efforts of Cecilia Razovsky and Varian Fry. Journal of Migration History, 4, 111-133.

\section{BYU ScholarsArchive Citation}

Shaw, Stacey, "Implications of the Second World War us Refugee Resettlement Efforts of Cecilia Razovsky and Varian Fry" (2018). Faculty Publications. 2932.

https://scholarsarchive.byu.edu/facpub/2932

This Peer-Reviewed Article is brought to you for free and open access by BYU ScholarsArchive. It has been accepted for inclusion in Faculty Publications by an authorized administrator of BYU ScholarsArchive. For more information, please contact ellen_amatangelo@byu.edu. 


\title{
Implications of the Second World War us Refugee Resettlement Efforts of Cecilia Razovsky and Varian Fry
}

\author{
Stacey A. Shaw \\ Brigham Young University, usA \\ stacey_shaw@byu.edu
}

\begin{abstract}
Despite anti-immigrant sentiment and severe restrictions on immigration to the us during the Second World War, many individuals and organisations fought to change attitudes and utilise the limited possibilities available. Cecilia Razovsky worked throughout this era to utilise quotas, increase awareness, and avoid negative attention that could hinder immigration. Varian Fry provided practical and legal assistance to refugees fleeing France until he was stopped by government officials. Razovsky has remained largely unknown but Varian Fry has drawn attention as an example of America's best intentions. The Second World War is frequently invoked in contemporary discourse surrounding immigration and the stories of rescue during that era continue to fascinate, as Fry's recognition shows. Through examining how the Us immigration advocates Cecilia Razovksy and Varian Fry responded to restrictions during the Second World War, this article asks why aspects of humanitarian memory persist and examines why particular aspects of their work continue to resonate and hold meaning for contemporary resettlement work.
\end{abstract}

\section{Keywords}

Refugee resettlement - Migration - The Second World War - Cecilia Razovsky - Varian Fry

* Acknowledgments: The American Jewish Historical Society generously provided access to the papers of Cecilia Razovsky. The Columbia University archival collections also permitted the author to access Varian Fry's personal correspondence, photographs, and other documents. Thanks are also due to Barbara Levy Simon, Patrick Poulin, and the anonymous reviewers who provided valuable feedback on drafts of this manuscript. 


\section{Introduction}

The United States was unwilling to accept large numbers of immigrants fleeing Europe before and during the Second World War. In the world's current refugee crisis, attention often hearkens back to the era of the Second World War. It is frequently mentioned that the number of people currently displaced exceeds that of the war - with explicit links made between the actions taken then and opportunities now. ${ }^{1}$ Despite differences in the nature of the conflicts, the ways in which refugees are represented, and the structures of international refugee regimes, the parallels that are made are motivated by the similarly vast scales of the displacement and persistent questions regarding who is entitled to international protection. ${ }^{2}$

During the Second World War a number of aid organisations and individuals worked to counter misconceptions about immigrants and overcome negative public sentiment, ${ }^{3}$ although opposition to strict and often punitive immigration policies among dis-united Jewish community leaders and others was not able to generate significant reforms. ${ }^{4}$ Many activist for refugees had a personal understanding of the need for assistance, through connections with family and community members or through direct experience in working with displaced people. Two refugee advocates from the us are particularly noteworthy as their actions assisted thousands of individuals at a time when support for displaced persons was extremely limited. Despite major obstacles, Cecilia Razovksy and

1 I. Tharoor, 'What Americans thought of Jewish refugees on the eve of World War II', The Washington Post 14 November 2015; E. Izadi, 'Anne Frank and her family were also denied entry as refugees to the U.s.' The Washington Post 24 November 2015; N. Kristof, 'Would you hide a Jew from the Nazis?' The New York Times 17 September 2016; P. Druckerman, 'If I sleep for an hour, 30 people will die', The New York Times 2 October 2016; D. Lind, 'How America's rejection of Jews fleeing Nazi Germany haunts our refugee policy today', Vox, 27 January 2017. Commentators also reference this era as a reason for the us not to intervene, see M. Qazvini, 'No, Muslim refugees are not Jewish wwin refugees. Here are 5 reasons why', The Daily Wire 18 November 2015 .

2 R. Karatani, 'How history separated refugee and migrant regimes: In search of their institutional origins', International Journal of Refugee Law 17:3 (2005) 517-541, 541.

3 H. Genizi, 'New York is big: America is bigger: The resettlement of refugees from Nazism, 1936-1945', Jewish Social Studies 46:1 (1984) 61-72, 61-63; I. Glynn, 'Stärkerer Einfluss, weniger Wohlwollen Reaktion zwischenstaatlicher Organisationen in Westeuropa auf die unerwünschte Migration in wirtschaftlichen Krisenzeiten im Vergleich', Comparative Population Studies 37:1-2 (2012) 121-146.

4 H.L. Feingold, The politics of rescue; the Roosevelt administration and the holocaust, 1938-1945 (New Brunswick 1970) 9-17; M. Hindley, 'Constructing allied humanitarian policy', Journal of Holocaust Education 9:2/3 (2000) 77-102, 94-95. 
Varian Fry worked with non-governmental organisations that were embedded within broader social and political contexts that were predominantly hostile towards immigrants, ${ }^{5}$ seeking to exploit potential opportunities for immigration and promoting increased openness to immigration among the public.

The efforts of these immigration advocates remain compelling within the light of present day worldwide concerns about migration. Perceptions of the us public and political leaders regarding migration responsibilities and opportunities today draw on political, social, economic, and religious concerns, but they also connect to historical memory, which can be observed by frequent references and comparisons to the Second World War in current discussions. Then and now, specific policy on refugees is linked to concerns surrounding migration, security, peace-building, human rights, and development, with state priorities generally emphasising strategic interests above humanitarian altruism. ${ }^{6}$ It is a complex undertaking to pinpoint how collective memory about immigration policy and services in the Second World War influences current immigration concerns. However, the way particular immigration advocates have been represented or lauded over time may demonstrate larger shifts in public understanding or awareness.

Through examining how the Us immigration advocates Cecilia Razovksy and Varian Fry responded to restrictions during the Second World War, this article asks why aspects of humanitarian memory persist and examines why particular aspects of their work continue to resonate and hold meaning for contemporary resettlement work.

\section{Materials and Methods}

The archival materials of Cecilia Razovsky are housed at the American Jewish Historical Society while the archive of Varian Fry is held at Columbia University. Razovsky's archive contains a wealth of documentation from different phases of her work, including memos, copies of letters, and notes for speeches, which give an idea to the scope of her daily efforts, relationships, and overall

5 P. Gatrell, "The world-wide web of humanitarianism: NGOs and population displacement in the third quarter of the twentieth century', European Review of History 23:1-2 (2016) 101-115, 102.

6 A. Betts, Conceptualising interconnections in global governance: The case of refugee protection (Refugee Studies Centre Working Paper Series 2006) 1-20, 11-12; A. Betts, 'International cooperation in the refugee regime', in: A. Betts and G. Loescher, (eds.), Refugees in international relations (Oxford 2011) 77-78. 
attitudes. While these records reveal a wide array of influence and involvement with thousands of cases, there is no coherent narrative of how her actions impacted particular individuals over time. The difficulty in pinpointing individual influence is likely due to the less prominent status of the individuals she served, as well as the collaborative nature of her work alongside her colleagues within the National Coordinating Committee (NCC). ${ }^{7}$ Additionally, a summary of Razovsky's work in her own words for a broader audience is not available, and assessments by her contemporaries are limited, despite what can be deduced from correspondence. Fry's archive contains less material documenting his activities as he did not maintain records while in France, ${ }^{8}$ however he was active in summarising his views for broader audiences after returning to the us, writing and submitting articles as well as books. Although both Razovsky and Fry interacted with prominent figures of the time, Fry was more likely to correspond with high profile artists and public figures, due in part to the assignments his work involved.

Information collected from the archives of these individuals as well as from secondary sources regarding their work and resettlement efforts during the 1930 s and 1940 s are included in this analysis. Although other sources have explored the personal experiences and contributions of Cecilia Razovsky and Varian Fry, this article examines specifically how they worked against us indifference and resistance to resettlement and includes content from previously unpublished material.

Both Razovsky and Fry acted as representatives of refugee communities, seeking increased access to immigration opportunities for those who saw them in a position of power to provide such assistance. As is largely the case today, refugees were often reliant on humanitarian agencies and had limited capacity to influence public opinion and policy. ${ }^{9}$ Razovsky and Fry differed in strategy, location, skills, and background, but both demonstrated individual engagement driven by a sense of urgency as well as a pragmatic approach that transcended the strategies and support of the organisations in which they worked. Through experience and understanding, they represented refugees as neither the 'solitary, heroic and contemplative exile' nor the minority 'threat to the status quo,'10 instead promoting recognition of common humanity and attempting to refute misconceptions.

7 Limited documentation of individuals Razovksy assisted is available in B.A. Zucker, Cecilia Razovsky and the American-Jewish Women's Rescue Operations in the Second World War (Portland 2008) 24-27, 169-174.

8 V. Fry, Surrender on demand: Afterward (New York 1945) 254.

9 Gatrell, 'The world-wide web of humanitarianism', 110.

$10 \quad$ P. Gatrell, Free world? The campaign to save the world's refugees (Cambridge 2011) 8. 


\section{us Immigration during the Second World War}

During the Second World War, attitudes towards refugee resettlement were negative overall..$^{11}$ Throughout the 1930s and 1940s, the majority of the American people and the us government supported restrictive immigration policies. In the pre-war period unemployment was widespread and an attitude of American self-sufficiency pervaded. ${ }^{2}$ The ongoing depression and accompanying unemployment concerns fostered anti-immigration sentiment, as did isolationism and anti-Semitism, which was widespread during the war. ${ }^{13}$ Mass media such as the Saturday Evening Post, which had the highest circulation of any Us magazine in 1937, included numerous articles attacking immigration and characterised incoming émigrés as undesirables who deserved sympathy but not American jobs and public relief. ${ }^{14}$ In a July 1938 Fortune poll, less than 5 per cent of respondents agreed that immigration quotas should be increased and people encouraged to come to the us, while over two thirds of those polled said, 'with conditions as they are we should keep [refugees] out'. In November 1938, shortly after the Kristallnacht, only 8.7 per cent of respondents supported increasing immigration quotas. Alongside this low rate of resettlement support, 94 per cent of respondents disapproved of the Nazis' treatment of Jews in Germany, ${ }^{15}$ suggesting that while sympathy existed it was coupled with an unwillingness to support immigration.

US immigration policy in the 1930s denied entry to anyone who could become a public charge or who might require any form of government support. Immigrants were required to name a family member or friend in the us who would provide an affidavit assuring ongoing financial support. ${ }^{16}$ Between 1933 and 1937 approximately 200,00o Jews left Germany, with most remaining in

11 Pew Research Center, U.s. public seldom has welcomed refugees into country, http://www .pewresearch.org/fact-tank/2015/11/19/u-s-public-seldom-has-welcomed-refugees-into -country/ (17 May 2017).

12 D.M. Kennedy, 'What the New Deal did', Political Science Quarterly 124 (2009) 251-268, 260-261, 263.

13 D.S. Wyman, Paper walls: America and the refugee crisis, 1938-1941 (Amherst 1985) 3-22; M. Potocky-Tripodi, Best practices for social work with refugees \& immigrants (New York 2002) 60 .

14 'Do we want more mouths to feed'? The Saturday Evening Post (1934) Sect. 22; I.F.; Marcosson, 'The alien in America'. The Saturday Evening Post (1935) Sect. 22-3, 110-113.; R.G. Carroll, 'Americans or aliens first'? The Saturday Evening Post (1936) Sect. 8-9, 114-121.

15 M.N. Dobkowski, The politics of indifference. A documentary history of Holocaust victims in America (Washington 1982) 267-268, 279.

16 D. Dwork and R.J. Pelt, Flight from the Reich: Refugee Jews, 1933-1946 (New York 2009). 
Europe or migrating to Palestine or South America. ${ }^{17}$ When the situation of displaced persons attempting to leave Europe reached crisis levels in 1938, the us government considered multiple resettlement schemes, including relocating people to the us territories of Alaska, the Philippines, and the Virgin Islands. These possibilities failed to develop into solutions due to local opposition, factions within the federal government that were opposed to changing immigration policy, and then a shift of political attention once the us entered the war in 1941. Other possibilities for resettlement in North Africa, Ethiopia, Angola, and British Guiana were delayed and ultimately discarded due to insufficient political will. ${ }^{18}$ The 1939 Wagner-Rogers Bill proposed the acceptance of 20,000 child refugees but ultimately failed due to a lack of public support, although approximately 1,00o unaccompanied refugee children came into the country. ${ }^{19}$ In 1939 the $M S$ St. Louis arrived in Cuba with 937 refugees on board, most holding quota numbers allowing them to enter the us. After a protracted period of waiting and eventual refusal of permission to come to the us, the ship returned to Europe. The American press and public recognised the tragedy of refusing sanctuary to refugees and sending them back to face persecution and possibly death. ${ }^{20}$ Attempts by Secretary Frances Perkins within the us Labor Department to increase immigration opportunities from Germany and secure special consideration for refugees did not succeed with the State Department, which secured control over immigration policy by 1940. us President Franklin D. Roosevelt was unwilling to publicly advocate increased support. ${ }^{21}$

International conferences and associations failed to reach concrete or widespread solutions to immigration needs. American James McDonald was appointed to be the first High Commissioner for Refugees within the League of Nations in 1933 through the support of Jewish organisations and because of his support within Germany, albeit with some hesitation on the part of the Us government over concerns that his role may jeopardise us immigration policy.

17 F. Caestecker and B. Moore, 'Refugees from Nazi Germany and the development of refugee policies, 1933-1937', in: F. Caestecker and B. Moore (eds.), Refugees from Nazi Germany and the liberal European states (New York 2010) 210-211.

18 Feingold, The politics of rescue, 77, 90-122; Wyman, Paper walls, 99-115.

19 D.E. Lipstadt, Beyond belief: The American press and the coming of the Holocaust, 1933-1945 (New York 1986) 112; J.T. Baumel, Unfulfilled promise: rescue and resettlement of Jewish refugee children in the United States, 1934-1945 (Juneau 1990) 9.

20 G. Thomas and M.M. Witts, Voyage of the damned (New York 1974) 23-306.

21 A.M. Kraut, R. Breitman and T.W. Imhoof, 'The State Department, the Labor Department, and German Jewish immigration, 1930-1940', Journal of American Ethnic History 3:2 (1984) $5-38,5,9-10,11$. 
After two years of failed attempts to facilitate resettlement or to negotiate with Germany ${ }^{22}$ McDonald resigned with a call for nations to intervene and assist. ${ }^{23}$ At the Evian Conference of 1938, President Roosevelt brought together representatives of $3^{2}$ countries to address the growing crisis, but countries were unwilling to modify restrictive policies or to overtly criticise Germany's anti-Jewish policy, resulting in no substantial resettlement opportunities and perhaps in increased border closures. ${ }^{24}$ The Bermuda conference in 1943 was an attempt to address public pressure to respond, but it led to no meaningful action. ${ }^{25}$ Efforts and sympathy expressed at Evian and Bermuda suggest there was some interest in helping, but ultimately this sentiment did not develop into action.

The us government made an exception to its immigration policy in the form of emergency visas for certain high-profile individuals. These visas, technically temporary, also required a guarantee of financial support and were issued to anti-fascist intellectual and cultural figures, including labour leaders, politicians, artists, musicians, writers, scientists, and clergymen. Approximately 2,000 individuals came to the Us through this arrangement, ${ }^{26}$ which started in 1940 and ended in July 1941. The programme was created in part through the efforts of the Emergency Rescue Committee, a group of journalists, religious leaders, intellectuals, and activists formed after the occupation of France by Germany.

In 1944 the notion of setting up free ports or temporary placements gained support among the public and the press. President Roosevelt favoured the idea, and eventually 1,00o refugees were admitted and housed in a restricted setting. This action may have assuaged some feeling of responsibility towards political refugees in need of asylum. ${ }^{27}$ In 1944 the War Refugee Board was established and called for increased assistance, but did not lead to the possibility

22 S. Heim, 'International refugee policy and Jewish immigration under the shadow of national socialism', in: Caestecker and Moore (eds.), Refugees from Nazi German, 17-47, 20-23.

23 Dwork, Flight from the Reich.

24 Feingold, The politics of rescue, 22-44; Heim, International refugee policy, 34-35.

25 P.A. Levine, 'Attitudes and action: Comparing the responses of mid-level bureaucrats to the Holocaust', in: D. Cesarani and P.A. Levine (eds.), Bystanders to the Holocaust: A reevaluation (London 2014) 212-236.

26 M. Halter, Stories of deliverance: Speaking with men and women who rescued Jews from the Holocaust (Chicago 1998).

27 Lipstadt, Beyond belief, 232-233. 
of relocation within the United States. ${ }^{28}$ Between 1933 and 1945 the Us admitted approximately 132,000 Jewish refugees. ${ }^{29}$

\section{Cecilia Razovksy (1886-1968)}

A child of Jewish immigrants who worked as an immigrant advocate and social worker with immigrants from 1909 until the 196os, Cecilia Razovsky was at the forefront of wartime resettlement efforts. She led the NCC, formed in 1934 and comprising of a group of private welfare agencies committed to supporting newcomers and others seeking immigration assistance. Razovksy served refugees through a careful, persistent approach to aid and interaction with the government, urging partners to exercise care in expression, not to work hastily, and to remain aware of the official's perspectives. ${ }^{30}$ Similar to social workers who shared an ethnic background with the immigrants they served in the 1920s, ${ }^{31}$ Razovksy was careful to adhere to restrictive guidelines while simultaneously seeking to exploit any potential avenues for admission and assistance. She sought to present immigrants in the best possible light, emphasising commonalities with the host communities as well as exceptional contributions immigrants could bring.

Throughout the 1930s nearly all assistance to refugees was provided by Jewish agencies, including refugees of other religious backgrounds. The NCC assisted individuals in securing employment, helped some to move to less densely populated areas of the Us, ${ }^{32}$ and provided information about legal procedures for people trying to secure safety for their relatives or themselves. Razovsky fought negative views towards immigration and struggled to ensure that the public charge clause was not violated, as examples of violations could

28 A.D. Morse, While six million died: A chronicle of American apathy (New York 1983) 313-342; Hindley, 'Constructing allied humanitarian policy', 94-95.

29 S. Mintz, Immigration policy in World War II, The Gilder Lehrman Institute of American History. https://www.gilderlehrman.org/history-by-era/world-war-ii/resources/immigra tion-policy-world-war-ii (17 May 2017).

30 American Jewish Historical Society Newton Centre, MA and New York, N.Y. Papers of Cecilia Razovsky (hereafter AJHS). Box 3, Letters, 3 November 1938, 4 November 1938, 21 November 1938.

31 Y. Schacher, 'Refugees and restrictionism: Armenian women immigrants to the USA in the post-World War I era', in: M. Schrover and D.M. Moloney (eds.), Gender, Migration and Categorization: Making distinctions between migrants in western countries, 1945-2010 (Amsterdam 2013) 55-74, 65 .

32 Genizi, New York is big, 64-65. 
jeopardise immigration opportunities for others. In 1934, Razovsky met with the us State Department regarding admittance for child refugees, assuring that the young people would not become public charges. Despite hopes that children would illicit a less negative response, Razovsky was dismayed at the opposition, including criticisms of 'sentimentality run riot', suggestions of children having Communist ties, and difficulty in finding suitable placements. Though widespread opportunities for children were not made available, the efforts of Razovsky and her colleagues did result in over 1,00o children being brought to the Us. ${ }^{33}$

In November 1938, in part due to the horrors of Kristallnacht, Razovsky described the office as receiving over 1,500 calls and sometimes 50 cables per day. She describes the atmosphere as feverish and tense, with people desperately seeking information and immigration opportunities for family members. ${ }^{34}$ She was placed in the difficult position of responding to desperate people who had limited or no chances of resettlement:

People all over the country have received similar cables. Persons who have received affidavits some time ago now want us to use our influence with Washington to get them out of Germany quickly. Of course that is absolutely out of the question. There is nothing we can do to help these thousands of trapped unfortunates. They have no preference in the quota and their turns will come two years hence possibly. ${ }^{35}$

The NCC's efforts centred on accessing available immigration slots for those in most need, a task requiring the dissemination of severe restrictions as well as persistent hope that more opportunities may become available in the us or elsewhere. Advising service partners to make immigration restrictions clear to people abroad and avoid raising people's hopes, ${ }^{36}$ Razovsky was forced to make difficult decisions about the allocation of scarce resources. Regarding a 67-year-old doctor attempting to immigrate as a physician, she wrote, 'I am sorry that I sound so hardhearted but the situation is so terrible that we can only think in terms of helping the younger people who have courage and physical stamina to overcome the obstacles which face us. ${ }^{37}$

33 Morse, While six million died, 252-269; Zucker, Cecilia Razovsky 41-53.

34 AJHS, Box 3. Letters, 3 November 1938, 21 November 1938, 25 November 1938.

35 AJHs, Box 3 . Letter to Greta Schaffner, 21 November 1938.

36 AJHS. Box 3. Letter, 7 November 1938, 9 November 1938.

37 AJHs. Box 3. Letter, 9 November 1938. 
In April of 1939 Razovsky addressed the National Council of Jewish Women in Chicago, summarising the sentiments that informed much of her work. She addressed both the necessity of increasing quotas and the importance of being empathetic and welcoming to those who arrive. First, regarding quotas:

If the entire quota from Central Europe is filled for people who wish to come into the United States, we can only receive into this country each year the total of 27,370 from Germany and Austria, with a possible several hundred more from that part of Czecho-Slovakia [sic] which has become greater Germany. If more countries are added to the dictatorship countries, there will probably be 2,00o more added - all in all, a total not above 30,000 . Thirty thousand in a population of 120 million is not great certainly the proportion is small, and when we read in the newspapers, as we do here in Chicago, of this great horde of refugees flooding America, taking away jobs from American citizens, creating depression - remember those figures and use them where they will do the most good! ${ }^{38}$

She went on to state that 1939 was the first time the quota had been filled, challenging negative attitudes towards refugees and soliciting empathy for their post-arrival circumstances. She then laments the limitations of the current immigration system:

The question is what shall we do? Where should we send them? [...] In the last few months, some of these cases have been the saddest in the whole history $[. .$.$] No country would let them land; they were stranded in$ mid-Ocean. To go back means Concentration Camp. It is a terrible feeling to be helpless to help those people. ${ }^{39}$

Drawing on strategies similar to those used by humanitarians today, Razovsky noted the extraordinary contributions that immigrants made to us society:

What are emigres contributing? They have found various ways of trying to earn a living - baking, making candies, etc. There is one man who is now manufacturing ski shoes and has engaged many American citizens to work for him. There has been a shop opened by a Viennese, who

38 AJHS. Box 5. Notes on talk given to the National Council of Jewish Women, Chicago. 26 April 1939 .

39 AJHs. Box 5. Notes on talk. 
previously had a similar shop in Vienna, making petit point - and many American citizens are being taught this work. Many American citizens are making a living and learning new trades, discovering new arts - arts and trades from Europe which produced articles which we used to import.

She then attacks the idea that refugees should be grateful, asking people to be patient and to try to identify with the experience of displacement:

When you consider these people had to give up everything they ever held dear, had to come to a new country and receive charity from organizations or relatives they had never met before, then you can understand why they seem to be different, why it is hard for them to quickly adjust themselves to their new environment. I wonder how we would feel - to take ourselves as example and become emotional - put yourselves in the place of the refugee who had children going to school, a good position, belonged to certain clubs, lived a completely comfortable life, transplanted in a new country where you don't even know the language, where you cannot find out where to go, where the customs are all strange: Where everyone is in a hurry and hasn't time to talk to you - to explain things: Where you cannot find a job: And from another country Wife and Children, Mother and Father, Sisters and Brothers, are sending you cables and sending letters, pleading, imploring, and your only thought is, 'How quickly can I earn money to send for them': Put yourself in their position and see what it means. You would feel lonesome and slighted and at your wits' end - and you would be better able to understand why some are apparently 'arrogant', etc. and so unhappy. Realizing these things, we have to bear with them until they get their bearings and making adjustment to this country. 40

Despite enormous obstacles, Razovsky was anxious to find ways to intervene particularly in desperate cases. Regarding individuals in concentration camps who had an affidavit on file, she expressed being 'convinced [we] can find a way to get them out to a neighboring country to await numbers on quota.41 Speaking of the numerous largely hopeless enquiries received from people requesting affidavits for non-relatives, Razvosky stated:

$40 \quad$ AJHS. Box 5 . Notes on talk.

41 AJHs. Box 3. Letter to Mr. Charles Strull, 25 November 1938. 
I wish to assure you that we would gladly do more for these people if we could. We are however, doing the best we can and in every case we write to them sympathetically so that they know their letter has received our attention. $^{42}$

Razovsky was haunted for decades by the tragedy of the St. Louis being turned away in $1939 .{ }^{43}$

In efforts to access legal immigration channels, Razovsky ensured that the NCC's work was conducted legally but avoided widespread public attention. Razovsky wrote that legislative efforts regarding resettlement locations would have the effect of 'creating and stimulating publicity which would undoubtedly bring about a great deal of prejudice and unnecessary discussion'. ${ }^{44}$ Cognisant of the role antisemitism played in negative attitudes towards immigration, Razovsky worked to frame the need for resettlement as political rather than religious:

One of the things of course, which is most important, is the question of public relation and propaganda from non-Jewish people so that they will know that this is not a Jewish issue but that Germans are being driven out of Germany, who are anti-present government. Some of them happen to be Jews; many of them have left the Jewish faith and would no longer be recognized either by Jews or non-Jews as Jews but all of them are people who are against the Nazi government and for that reason are being punished. ${ }^{45}$

Agencies blocked the hearings for two bills that would give unused immigration quota to refugees in congress in 1938, fearing the attention would give restrictionists a chance to win broader opposition and potentially end all immigration. These reservations persisted into the early 1940s, when immigration activists feared that lobbying for refugees could end immigration and negatively impact fundraising efforts. ${ }^{46}$

By 1942 refugee advocates recognised that resettlement would not occur and it became even more difficult for Jews to leave Europe. ${ }^{47}$ Advocates continued

42 AJHS. Box 3. Letter to Supreme Court Justice Louis D. Brandeis, 22 November 1938.

43 AJHs. Box 3. Memo. September 1961.

44 AJHS. Box 3 . Letter to Eugene Blumenthal, 8 November 1938.

45 AJHS. Box 3. Letter to Helen M. Perkins 29 November 1938.

46 Wyman, Paper walls $67-68$.

47 Feingold, The politics of rescue, 90-166; R. Cohen, 'The lost honour of the bystanders? The case of Jewish emissaries in Switzerland', in: Cesarani and Levine (eds.), Bystanders to the Holocaust, 146-170. 
to work for changes in policies, seeking to change adjustment-of-status restrictions, looking for ways to transfer work qualifications, and encourage the reconsideration of rejected visa applications. Razovksy and others persistently fought misinformation and bias, which included confronting members of Congress that had issued false statements about refugees using public resources. Due to the lack of immigration options for the Us, Razovsky investigated the possibilities for securing temporary visas, including tourist, student, or other travel options to Panama, Costa Rica, the Dominican Republic, Australia, the Philippines, and Cuba, as well as transit visas, which were available for high prices in some European countries. ${ }^{48}$

Razovsky's approach demonstrates a keen awareness of the limits of public charity and political will alongside persistence in strategic advocacy and her ability to devise creative solutions for individuals and their families. Recognising anti-Semitism and anti-immigrant sentiment, she sought ways to play down religious identity and even sought to avoid political actions that would draw unwanted or unhelpful attention. Alongside her colleagues, Razovsky quietly assisted thousands of refugees fleeing Europe over a period of many years through advocacy and direct support.

Despite her contributions, towards the end of the war Razovsky was demoted and her role limited. After the NCC merged with two organisations to form the National Refugee Service (NRS) in 1939, Razovsky's role shifted from Executive Director (at NCC) to Director of the Migration Department, then to Assistant to the Executive Director (August 1940) ${ }^{49}$ In 1943 alongside organisational restructuring her role was changed to Consultant. In addition to the change in title, Razovsky's salary was reduced from $\$ 7,000$ to $\$ 5,000$ and her duties were restricted to specifically outlined tasks (dealing only with cases referred to her by the agency, representing the agency only on assigned cases, advising the executive director regarding agency policy or in relation to responses on assigned cases, and representing the agency at inter-agency meetings and speaking engagements). After these changes came into effect Razovsky resigned. In a letter, she indicated that she was not concerned about the pay cut or change in job title but was unsure about the value of her contribution and questioned the limitations of the position. ${ }^{50}$

Undaunted by these setbacks Razovsky went on to work for the United Nations Relief and Rehabilitation Agency in Europe and in 1944-1945 worked

\footnotetext{
48 Zucker, Cecilia Razovsky 106.

49 AJHs. Executive Office Memorandum, 26 July 1940.

50 AJHS. Box 5 . Letter to Miss Cecilia Razovsky from Albert Abrahamson, 8 January 1943, Letter to Mr. Rosenwald, 28 December 1942, Interoffice memorandum from Joseph E. Beck to Miss Cecilia Razovsky, May 41943.
} 
for the American Jewish Joint Distribution Committee directing emigration for Germany and Austria. After the war she continued to advocate for immigration liberalisation ${ }^{51}$ and worked to support the immigration of Jewish refugees to Brazil. Though she officially retired in 1950, she continued to be involved in advocacy and service efforts, even supervising refugee resettlement and immigration in Brazil and other Latin American countries for the United Hebrew Immigrant Aid Society Service (HIAS) at the age of 70. At the age of 80, a year before her death, she chaired the International Committee for Social Work in San Diego, working to organise an agency to support Mexican-Americans. ${ }^{52}$ Since her death Cecilia Razovsky has been noted as a female Jewish leader ${ }^{53}$ but not widely recognised.

\section{Varian Fry (1907-1967)}

A group of leftist journalists, religious leaders, intellectuals, and activists formed the Emergency Rescue Committee (ERC) after the occupation of France by Germany in 1940. ERC member Varian Fry volunteered to bring funds to Marseilles. ${ }^{54}$ His original mandate to locate 100 people over a period of one month grew as he recognised the scope of the crisis. Fry and his colleagues were involved in the escape of over 15,000 people from France, assisting at least 1,000 refugees to migrate to the Us and supporting hundreds in Marseille with food and shelter. 55

After 13 months Fry was forced to leave France due to indifference from the US consulate and threats from the Vichy government. In June 1941, Fry wrote to the head of the ERC asking him to 'point out [to the Us State Department] the diplomatic value of the pawn which I constitute. ${ }^{56}$ In July, Fry received word that the ERC and the Us State Department continued to press for his return to the Us. He felt that if either group were to favour continued rescue efforts, the Vichy government would permit the organisation to continue operating. In mid-August the Vichy government office told Fry he could stay if the American

$5^{1} \quad$ Zucker, Cecilia Razovsky ${ }^{162-165}$.

$5^{2}$ AJHs. Box 2. Letter to Read Lewis, 18 January 1967.

53 Zucker, Cecilia Razovsky 1-3, 7, 165; M. McCune, Cecilia Razovksy.Jewish Women:A comprehensive historical encyclopedia (Jewish Women's Archive 2009). http://jwa.org/encyclope dia/article/razovsky-cecilia (18 May 2017).

54 Fry, Surrender on demand xii.

55 Wyman, Paper walls 141-142; Columbia University Rare Book and Manuscript Library, Varian Fry papers (hereafter $\mathrm{CU}$ ).

$5^{6} \quad$ CU, Varian Fry, 1941. 
Embassy would say a word in his favour. Although American consuls had limited power under Vichy leadership and punctilious examination of documentation for potential migrants was required, officers maintained some level of freedom in processing visas and affidavits. ${ }^{57}$ Fry observed that the American consuls did not make the most of the powers they possessed to offer protection although he describes an exception in Vice Consul Harry Bingham's efforts to provide personal and professional assistance (Bingham was later demoted and his career in the us foreign service terminated due to these efforts). Fry's wife Eileen wrote to Eleanor Roosevelt, who had previously been an advocate of the emergency visa programme, petitioning that he be allowed to stay in France. Eileen received a note in return stating, 'He has done things which the government does not feel it can stand behind, ${ }^{58}$ Fry concluded that the American Consul was unwilling to support the group's work due to a similar lack of interest in rescuing these persecuted groups. ${ }^{59}$ Towards the end of August 1941 officers of the Vichy government arrested Varian Fry, accused him of engaging in secret activities, and he was forced to leave the country. No Emergency Rescue Committee successor arrived. ${ }^{60}$

Fry embodied vision and persistence, as his efforts far exceeded his original organisational mandate and he sought to exploit any potential avenue for assistance. He was personally engaged and desperate for others to join the cause, regardless of restrictions or risks, but ultimately his role in France was curtailed and his efforts to stay involved in advocacy were not widely supported or impactful. After returning to the us Fry was excluded from resettlement work and his calls for further intervention went unheeded. ${ }^{61}$ In 1943 Fry wrote to the us Congress in support of a bill to allow temporary entry for refugees, urging caution regarding the barring of those who may become public charges or who have a criminal record, as many people involved in opposition work had been designated criminals. Fry's 1945 book about his rescue experiences, Surrender on Demand, did not include his foreword, which stated:

The living [...] do not want to die. Go, they said, go back and make America understand, make Americans understand and help before it is too late

\footnotetext{
57 Dwork, Flight from the Reich.

$5^{8}$ CU, Varian Fry, 1941; S. Isenberg, A hero of our own (New York 2001) 75, 150, 171, 193. Fry, Surrender on demand, 251.

59 CU, Varian Fry, 1941.

6o CU, Varian Fry; Fry, Surrender on demand, 206-226.

61 V. Fry, 'The massacre of the Jews', New Republic (1942) 816-819; Fry, Surrender on demand, 254-255.
} 
[...] People don't understand [...] because what they see they see distantly, impersonally [...] They haven't seen it, heard it, smelt it, so it doesn't move them. ${ }^{62}$

Surrender on Demand was advertised as an adventure story about a naïve American rescuer of European cultural elites - 'He rescued famous men and women on the Gestapo black list!'63 Fry's book was largely unavailable until it was reprinted in 1997.

During the 1950s, Varian Fry was involved in a number of projects and received an unsettling response from the us Department of Defense after asking for access to material for a documentary film. His request was denied and he was accused of having been an active Communist party member since 1937 as well as a sympathetic associate of other party members. Fry asserted that his beliefs and actions were strictly anti-Communist, obtaining letters of support and clarification from friends and associates to multiple government officials. Months later he received notification that his access to the requested documents had been approved without further explanation. Fry began constructing the story of his life and attempted - unsuccessfully - to find someone willing to publish a story about his wrongful accusation. ${ }^{64}$

As collective awareness shifted towards criticism of countries' and nonJews' failure to act before, during, and after the war, interest in Varian Fry began to grow. In the 196os Fry was recruited by the International Rescue Committee (IRC) to help fundraise for relief efforts. ${ }^{65}$ In 1965 the New York Times Magazine asked Fry to write an article about the rescue mission in Marseille to commemorate 25 years from the time his work began. The magazine wanted the article to emphasise the famous individuals among those that had been rescued. The IRC told Fry of the request and submitted the article on his behalf, but the magazine claimed that the article would not fit in the space they had available. The IRC then submitted the story to the New Yorker where it was also rejected. ${ }^{66}$ There was however a growing fascination with certain elements of Fry's story - specifically those parts related to celebrity and adventure. Fry was engaged in the IRC's fundraising efforts until the end of his life, communicating with artists regarding possible donations of art. He wrote in 1967 about the futility of his efforts and his experience of persistent pain without adequate

\footnotetext{
62 Fry, Surrender on demand: Unpublished Foreword, 242.

63 Cu, Varian Fry. Advertisement for Surrender on Demand. 30 March.

64 CU, Varian Fry.

65 Fry, Surrender on Demand: Afterword, 258-259.

66 CU, Varian Fry. Letter from Ned McGuire, 25 August 1965.
} 
medical support. ${ }^{67}$ France awarded Fry with the Legion d'Honneur in 1967, shortly before he died in relative obscurity.

More recently Varian Fry and his activities have gained increased attention, with various posthumous awards being made in the us and abroad. ${ }^{68} \mathrm{He}$ has been represented as an inspirational figure, both in Isenberg's 2001 biography entitled A Hero of Our Own and in films by David Kerr - Varian Fry: The artists' Schindler (1997), and Lionel Chetwynd - Varian's war: The forgotten hero (2001). The IRC and the Varian Fry Foundation sent resources including Fry's book, a video, and resource guides to all secondary schools in the us during the 1999-200o school year. ${ }^{69}$ The IRC includes information about Fry on their website, noting, 'it was many years before Fry's exploits won the recognition they deserved. ${ }^{70}$ The IRC's Airbel Center is named after the Air-Bel Villa in Marseille from which Fry helped thousands to escape to freedom. ${ }^{71}$

\section{Reflection on Perceptual Shifts}

Interest in the heroic accounts of those involved in war rescue is abundant and persistent. ${ }^{72}$ While Fry is now remembered and praised, he still remains

67 CU, Varian Fry. Letter to Jacques Lipchitz, 6 March 1967.

68 U.s. Holocaust Memorial Museum, Holocaust encyclopedia: Varian Fry, 2016, https:// www.ushmm.org/wlc/en/article.php?ModuleId=10005740 (17 May 2017); Yad Vashem, An American in Marseille, http://www.yadvashem.org/righteous/stories/fry (17 May 2017); J. Guillon, 'Varian Fry et le centre américain de secours', Vingtième Siècle. Revue d'histoire 64 (1999) 133-135; https://www.govtrack.us/congress/bills/11o/hres743/text (17 May 2017);

69 International Rescue Committee: Varian Fry (2010) https://web.archive.org/web/20101 222193838/http://www.theirc.org/varian-fry (17 May 2017); The Varian Fry Foundation project/IRC, http://www.almondseed.com/vfry/fryfoun.htm (17 May 2017).

70 International Rescue Committee: Varian Fry (2010) https://web.archive.org/web/201012 22193838/http://www.theirc.org/varian-fry (17 May 2017); Rescuing the Nazis' 'most wanted', https://www.rescue.org/article/varian-fry-rescuing-nazis-most-wanted (17 May 2017).

71 International RescueCommittee,AirbelCenter, https://www.rescue.org/airbel-center\#why -airbel (8 January 2018).

72 E. Land-Weber, To save a life: Stories of Holocaust rescue (Urbana 200o); M. Paldiel, Saving the Jews: Amazing stories of men and women who defied the 'final solution' (Rockville 2000); C. Fenyvesi, When angels fooled the world: Rescuers of Jews in wartime Hungary (Madison 2003); P. Hellman, When courage was stronger than fear: Remarkable stories of Christians and Muslims who saved Jews from the Holocaust (New York 2004); M. Klempner, The heart has reasons: Holocaust rescuers and their stories of courage (Cleveland 2006); M. Paldiel, Diplomat heroes of the Holocaust (Jersey City 2007); C.T. Boom, The hiding place (Jersey City 2006). 
less well known than other heroic figures of the era, such as Oskar Schindler, who captured America's imagination through the Hollywood depiction of his experience in Schindler's List, while relieving American audiences of any guilt by portraying the Holocaust as a primarily German and Austrian issue. ${ }^{73}$ In contrast, the efforts of other extraordinary refugee advocates throughout this era, such as Cecilia Razovsky, have not been widely recognised. Contemporary American audiences may identify more directly with a white Protestant man serving intellectuals and artists (Varian Fry), than with a Jewish woman (Razovsky) serving people who became refugees strictly because of their religion or political persuasion. Alternately, perhaps Razovsky's quieter, always technically legal approach to helping non-famous individuals draws less interest.

Major changes in representations of Varian Fry over time suggest his story continues to generate meaning within the public mind-set as well as for humanitarian organisations and governments. Research examining changes in the way refugees are represented over time has salience here. ${ }^{74}$ As the way refugees are depicted may be calculated to have a certain effect on donors and policy makers, so to the appropriation of advocates such as Fry may serve to create a sense of historical continuity and visibility. In the case of the International Rescue Committee, the fact they have highlighted Fry's foundational role is somewhat ironic, and historically incomplete, given that the organisation had refused to support the continuation of his work in 1941 and in doing so limited his activities. Recognition of Fry from the us government has also glossed over the difficulties he faced, including the prohibition of his work and accusations of Communist links. Humanitarian organisations may utilise subjective memory to enable cohesion and strengthen self-narratives, ${ }^{75}$ but how does Fry's experience as an advocate and foundational member of the organisation influence the agency's current work? Recent representations of Fry may be based on the utility that parts of his story or connection to his work now provide. While this suggests that his advocacy work is seen as valuable and valid, it is less clear whether attempts to utilise his methods would likewise be welcomed in the current political climate.

73 S. Spielberg, Schindler's List (Universal 1993); I. Avisar, 'Holocaust movies and the politics of collective memory', in: A.H. Rosenfeld (ed.) Thinking about the Holocaust after half a century (Bloomington 1997) 38-6o; A.L. Mintz, Popular culture and the shaping of Holocaust memory in America (Washington 2001) 150.

74 Gatrell, Free world? 8-9, 248-249; P. Gatrell, The making of the modern refugee (Oxford 2013) 5-9.

75 B. Taithe and J. Borton, 'History, memory and "lessons learnt" for humanitarian practitioners', European Review of History 23:1-2 (2016) 210-224, 214, 217-218. 
The Second World War rescue efforts remain a part of America's collective guilt and fascination. As time grows between the present and war, public understanding is built more upon learning and interpretation than direct experience. Collective memory in the us is fragmented, due to the diversity of the population and frequent changes occurring within groups and subgroups. Despite this heterogeneity, events surrounding the Holocaust retain a powerful influence on American culture and morality, and Holocaust-related consciousness persists. Questions surrounding the historical implications of the loss of life and opportunities during the war likewise continue. ${ }^{76}$ The recognition of Fry as a hero may result from the drama of his personal story, but also a belief that his views and efforts should have been supported by the public and government during his lifetime. Identifying with a hero may suggest a will to correct past actions; however, sentiment towards Fry could merely signify hero fascination without a further understanding of what occurred and why it was not more broadly supported. Like a fascination with horror, this interest in heroes can amount to nothing more than a glimmer of awareness. ${ }^{77}$ Alternately, collective memory can lead to questioning, where symbols are used to examine the relationship of the present to the past and to redefine the collective present. ${ }^{78}$ The present can thus be defined as a place where different actions would have been taken in similar circumstances. Linking sentiment about Fry to current resettlement efforts raises new questions of collective perception towards empathy, responsibility, and action. Shifting perceptions of Varian Fry may indicate whims related to nostalgia and entertainment, notions about the 'other' and focused regret, or some level of identification and a desire to act differently. The way Varian Fry's story has been portrayed raises questions about what underpins these shifts but does not demonstrate a significant ideological change towards immigration opportunities. The historical understanding of humanitarian organisations remains fragmented. ${ }^{79}$ The development of a sanitised memory of Varian Fry accompanied by the absence of remembrance of Cecilia Razovsky suggests attention to these advocates is based less on the essence of their contribution than on nostalgia and a wish to exploit their

$7_{6}$ J. Shandler, 'Aliens in the wasteland: American encounters with the Holocaust on 196os science fiction television', in: H. Flanzbaum (ed.), The Americanization of the Holocaust (Baltimore 1999) 33-45; P. Novick, The Holocaust in American life (Boston 1999) 1-4, 278; T. Kushner, "Pissing in the wind"? The search for nuance in the study of Holocaust "bystanders", The Journal of Holocaust Education 9:2 (2000) 57-76; D. Bloxham and T. Kushner, The Holocaust: Critical historical approaches (Manchester 2005) 1-3.

77 Kushner, Pissing in the wind 61.

78 Novick, The Holocaust in American life.

79 Taithe and Borton, History, memory, 218-219. 
current value, though present immigration circumstances call for a further challenge of these piecemeal representations.

\section{Implications for Present Resettlement Efforts}

Contrasts between Fry and Razovsky's work and today's bureaucratised resettlement system are striking. After the Second World War the international refugee regime was established ${ }^{80}$ in a form that persists today, led by UNHCR and a proliferation of non-governmental organisations that subsequently shaped what it means to be a refugee. ${ }^{81}$ While humanitarians advocating for refugee resettlement today may share the sentiments and strategies used by Cecilia Razovsky and Varian Fry, their role is inherently restricted. In the unlikely possibility that a special visa programme could be created to assist artists and religious leaders from countries such as Syria or Somalia, it is difficult to imagine that a worker could expand their reach to secure visas for additional individuals in need, as Fry did. Refugee resettlement service providers would not be in a position to go beyond providing basic assistance to newcomers, such as employment and housing, while simultaneously giving strategic feedback to individuals abroad seeking to migrate, negotiating possibilities for exceptions with the state department, seeking immigration possibilities in other countries, and communicating with political leaders including a Supreme Court Justice and us Secretary to the Treasury, ${ }^{82}$ as Razovsky did.

While differences in social contexts including the professionalisation and expansion of refugee service structures make comparisons almost quaint, persisting parallels suggest the state to which humanitarianism has evolved deserves questioning. Since the us resettlement programme was formalised in 1980 , the number and origins of those who are granted resettlement to the Us has varied by a yearly presidential appointment. While 84,995 refugees arrived in fiscal year (FY) $2016^{83}$ the initial presidential appointment of 110,00o for FY $2017^{84}$ has been modified through a series of executive orders by the current

\footnotetext{
8o Betts and Loescher, Refugees in international relations, 8.

81 Gatrell, The making of the modern refugee, 5-11.

82 AJHS. Box 3. Letters to Stephen S. Wise 4 November 1938, 22 November 1938, 8 December 1938, Memo regarding case 10 November 1938.

83 US Department of State, U.s. refugee admissions program https://www.state.gov/j/prm/ ra/admissions/index.htm (18 May 2017).

84 U.s. State Department, Proposed refugee admissions for fiscal year 2017, https://www.state .gov/j/prm/releases/docsforcongress/261956.htm (18 May 2017); us Department of State,
} 
Us president to 45,000 for FY $2018 .{ }^{85}$ Razovsky encouraged audiences to reflect on the paltry number of at best 30,000 places for those seeking resettlement opportunities in the pre-war era, particularly in light of the size and population of the Us. ${ }^{86}$ Where over 65 million people are displaced worldwide, including 21.3 million designated as meeting the technical refugee definition by UNHCR in $2015,{ }^{87}$ the contribution of the Us to providing immigration opportunities to those in need is negligible. While the contribution is minor, the us has traditionally provided the majority of the world's permanent resettlement opportunities. ${ }^{88}$ That role appears to be changing as Europe responds to the current crisis, with Germany registering over a million asylum seekers during $2015^{-2016.89}$

Discussing the failure of the refugee service regime to generate wide-scale resettlement opportunities is not the aim of this article, although giving further attention to how and why the humanitarian strategies and scope have evolved over time is necessary. UNHCR is limited by its mandate to be non-political, non-operational, and most fundamentally, to maintain member state support. ${ }^{90}$ As migration policy remains focused primarily on limiting unwanted immigration and protecting national territory, ${ }^{91}$ efforts for refugee protection

us Department of Homeland Security, Department of Health and Human Services, Proposed refugee admissions for fiscal year 2016: Report to the Congress (2015).

85 The White House, Executive order protecting the nation from foreign terrorist entry into the United States, https://www.whitehouse.gov/the-press-office/2017/03/o6/executive-order -protecting-nation-foreign-terrorist-entry-united-states (18 May 2017).

86 AJHs. Box 5. Notes on talk given to the National Council of Jewish Women, Chicago. 26 April 1939. Immigration policy was based on quotas for particular countries. Another estimate suggests that the number of spaces potentially available to refugees from European nations under Nazi rule was 53,00o per year. Feingold, The politics of rescue, 126.

87 UNHCR, Figures at a glance, http://www.unhcr.org/en-us/figures-at-a-glance.html (18 May 2017); A refugee may be granted official status by UNHCR due to a well-founded fear of persecution based on protected categories of race, religion, nationality, membership in a particular social group, or political opinion, UNHCR, Protecting refugees \& the role of UNHCR, http://www.unhcr.org/en-us/about-us/background/509a836eg/protecting -refugees-role-unhcr.html (18 May 2017), us Department of State, Background briefing: Us government officials on the refugee cap for fiscal year 2018, https://www.state.gov/r/pa/prs/ ps/2017/09/274464.htm (8 January 2018).

88 UNHCR, Resettlement data: Submissions and departures since 2013, http://www.unhcr.org/ en-us/resettlement-data.html; Submisssions and departures since (17 May 2017).

89 Amnesty International, Germany 2016/2017 http://www.amnesty.org/en/countries/europe -and-central-asia/germany/report-germany/ (17 May 2017).

$90 \quad$ Gatrell, The world-wide web of humanitarianism, 102.

91 Heim, International refugee policy, 18. 
are based partly if not predominantly on strategic national interests, for example, providing resettlement opportunities for those fleeing Communism as a means to discredit the Soviet Union during the Cold War. ${ }^{92}$ Recognising the limitations which political contexts impose on broader resettlement efforts, the aim of this analysis is to draw upon evolving perspectives of war efforts and highlight what they say about present resettlement work.

The anti-Muslim rhetoric that abounds today echoes the experiences of anti-Semitism that hindered resettlement efforts in the 1930s. Nationalistic nativism persists, driving parallel concerns about economic security and terrorism. Public sentiment plays a major role in a country's willingness and subsequent ability to provide refuge. Fears of cultural threat and economic scarcity influence support and political decisions. ${ }^{93}$ These perspectives change as additional information becomes available and time passes beyond the point of conflict and crisis, as is apparent in the sympathy demonstrated now towards refugees fleeing Europe in the 1930 s and 1940s, and in the identification and celebration of people such as Varian Fry who were able to provide extraordinary, even extra-legal assistance to people in need of refuge. While the us remains geographically isolated from the primary influx of migrants occurring in Europe, the social connectivity of the world allows constant and immediate awareness of people's plight and suffering. Ease of travel provides access and possibilities for immediate relief and service structures such as the UNHCR can enable a more coordinated and internationally collaborative response.

Cecilia Razovsky called for recognition of oneself in the plight of an individual seeking refuge, 'So when you are asked to help in the cause, bear these things in mind and say with others- There but for the grace of God, go I'!94 Strategic interests were not enough to inspire most individuals and nations into action during the Second World War, where intervention required an 'inordinate passion to save lives and a huge reservoir of good will toward Jews. ${ }^{95}$ Identification with war heroism and the will to have provided asylum to Jews and others fleeing German territory during the atrocities of war remains hollow if us communities are unwilling to respond more comprehensively to the needs of refugees fleeing persecution today. Over time perceptions change as the understanding of the horror people experience increases, and fears about imagined differences subside. The stance of many Americans towards

92 Betts and Loescher, Refugees in international relations, 9.

93 J.S. Fetzer, Public attitudes toward immigration in the United States, France, and Germany (Cambridge 2000) 107-109.

94 AJHs. Box 5. Notes on talk. 26 April 1939.

95 Feingold, The politics of rescue, 301. 
the suffering experienced during the 1940s suggests a will to have done more during the war. Identification with the full experience of advocates such as Varian Fry promotes a notion that wider scale resettlement is possible and worth attempting. Altruism may be less salient than other strategic interests for sovereign states seeking border security, ${ }^{96}$ but in hindsight those interests blur. The limits of support for advocates such as Razovsky and Fry continues to influence a sense of responsibility, and guilt, regarding a collective us response to forced migration.

96 Betts, Conceptualising interconnections, 11; Betts, International cooperation, 77-78; D. Parsanoglou, 'Organizing an international migration machinery: The intergovernmental committee for European migration', in: L. Venturas (ed.), International 'migration management' in the early cold war: The Intergovernmental Committee for European Migration (Tripolis 2015) 55-86, 51. 